\title{
Applications of Mindfulness in Psychotherapy - Contemporary Dilemmas
}

\author{
Borut $\check{S} K O D L A R^{*}$
}

\begin{abstract}
Mindfulness has without doubt been the fastest spreading and most popular concept in psychotherapy in the last two decades. Its influence exceeds that of any other individual concept or approach in modern psychotherapy. However, there are many dilemmas, open questions and controversies related to this rapid, almost fanatic spread, which obviously compensates for a certain lack in modern Euro- and Americo-centric societies. Similarly, we are witnessing in the West a lack of reflection, a process of limitless idealization, and the search for a panacea. This all flows with a tint of colonialism, presumptuously taking over ideas, concepts and techniques without a proper study of the primary sources, and with all the accompanying negative side-effects: profiteering, self-promotion, unethical conduct, empty promises of instant rewards, and so on. In the present paper, the development of interest in mindfulness in psychotherapy, as well as the research findings and dilemmas, and concepts and mechanisms of applying mindfulness in psychotherapy, will be reviewed. The main purpose of the paper is to contribute to the critical reflection in studying and applying mindfulness in psychotherapy.
\end{abstract}

Keywords: mindfulness, meditation, psychotherapy, psychotherapy research

\section{Izvleček}

Čuječnost je v zadnjih dveh desetletjih zagotovo koncept, ki se najhitreje širi in je najbolj odmeven v psihoterapiji. Je vplivnejši od kateregakoli drugega posameznega koncepta ali pristopa v sodobni psihoterapiji. Vendar so ob tem hitrem, skoraj fanatičnem širjenju, ki očitno nadomešča določena pomanjkanja v sodobnih evropskih ali ameriških družbah, prisotne številne dileme, odprta vprašanja in razhajanja. Prav tako smo na Zahodu priča pomanjkanju refleksije, procesu brezmejne idealizacije in iskanju panaceje. Vse to poteka $z$ določeno stopnjo kolonialistične naravnanosti, ki samozaverovano jemlje ideje, koncepte in tehnike, brez poglobljenega študija primarnih virov in z vsemi negativnimi stranskimi učinki, kot so dobičkarstvo, samo-promocija, neetično ravnanje, prazne obljube o takojšnjem uspehu ipd. V pričujočem besedilu so predstavljeni razvoj zanimanja za čuječnost $\mathrm{v}$ psihoterapiji, izsledki raziskav in dileme $\mathrm{v}$ raziskovanju ter koncepti in mehanizmi

Borut ŠKODLAR, Associate Professor, University Psychiatric

Clinic Ljubljana.

borut.skodlar[at]psih-klinika.si

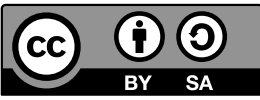


pri aplikaciji čuječnosti v psihoterapiji. Njegov glavni namen je prispevati h kritičnemu premisleku o proučevanju in aplikaciji čuječnosti v psihoterapiji.

Ključne besede: čuječnost, meditacija, psihoterapija, raziskovanje v psihoterapiji

\section{Introduction}

Mindfulness has in the last two decades become the most popular concept in psychotherapy. It has thus overshadowed any other singular psychotherapeutic format or approach, and has also spread widely outside the traditional psychotherapeutic domains, into areas such as relationships, pregnancy and childbirth, parenting, education, business and management, even politics, the military and prisons, some areas with high ethical awareness, and some completely without it.

There are many dilemmas, open questions and controversies in relation to this fast, almost fanatic spread, which obviously compensates for a certain deficit in modern Euro- and Americo-centric societies. The need for stronger contact with one's body and bodily feelings, greater transparency in relation to emotions, as well as a search for peace, relaxation and other salves against the increasing pressure and expectations of modern life-styles, seem to be just a few of the manifestations of such a deficit.

Indirect expressions of a certain latent need in society are also an indication of a lack of reflection, a process of limitless idealization and the search for a panacea. Mindfulness has thus been applied, as noted above, in a very wide and growing range of domains.

However, all of the above-mentioned manifestations of mindfulness in the West have a tint of colonialism, presumptuously taking over ideas, concepts and techniques without a proper study of the primary sources. With this process of secularization, change in contexts and more or less intentional forgetting of certain, predominantly ethical aspects, the original Buddhist sources no longer seem worth studying (Ditrich 2016). The related teachers and knowledge-holders have become mindfulness-oriented psychotherapists, as reflected in the courses they teach and the textbooks they have written.

These processes of decontextualization and secularization have given rise to a number of negative side-effects, such as profiteering, self-promotion, unethical conduct, empty promises of instant rewards, and so on.

The present article aims at first exploring the development of interest in mindfulness within the context of psychotherapy, then reviewing some of the research 
findings and dilemmas, and finally outlining and discussing concepts and mechanisms in applying mindfulness in psychotherapy. All of this is undertaken with a single purpose in mind, to contribute to greater critical reflection in this area, which is currently much needed in studying and applying mindfulness in psychotherapy.

\section{Development of Interest in Mindfulness within the Context of Psychotherapy}

Interest in meditation and mindfulness within the field of psychotherapy has not been a recent development. Instead, it is a tradition that dates back to some of the founding fathers of modern psychology and psychotherapy, such as William James, Carl Gustav Jung or Erich Fromm (Lenoir 1999) in an international context, and Lev Milčinski (1990) in the Slovenian one. The important intermediate place between the pioneers and contemporary mindfulness-oriented psychotherapists is occupied by serious scholars of Buddhist psychology, like Jack Kornfield, Joseph Goldstein, Jack Engler, Mark Epstein, Sharon Salzberg and others in an American context, and Primož Pečenko (1990) and Tamara Ditrich (2013) in Australia and Slovenia. These scholars all have studied through their own intensive practice in various meditation centers in Asia under the guidance of renowned meditation masters.

The starting point for the rapid spread of the use of mindfulness in the medical context was the formation of the Mindfulness-Based Stress Reduction (MBSR) program by Jon Kabat-Zinn, in 1979 at the University of Massachusetts Medical Center. Kabat-Zinn has studied with Zen masters, like Thich Nhat Hanh and Seungsahn, as well as with some of the aforementioned meditation teachers, like Kornfield, Goldstein and Salzberg, at the Insight Meditation Society in Barre, Massachusetts. MBSR was designed and first applied at the Stress Reduction Clinic of the University of Massachusetts Medical Center in order to help patients with chronic pain, who had unsuccessfully tried other forms of treatment (Kabat-Zinn 2013).

Interest in meditation and mindfulness in psychotherapy can be broadly divided into three strands: 1) Interest in (phenomenological) descriptions of diverse meditative and altered states of consciousness, and the different psychological systems comprising them. Among the first researchers that focused on exploring these topics are influential scholars such as Thomas William Rhys Davids and William James, as well as contemporary representatives of this lineage, like Chögyam Trungpa Rinpoche, the Dalai Lama, Francisco Varela, Arthur Zajonc, Daniel Goleman, Richard Davidson, Alan B. Wallace and other researchers, related to 
the Mind and Life Institute, which was established to study these phenomena. 2) Narrower interest in a dialogue and the transmission of knowledge and insights from meditative and mindfulness practices into psychotherapy. This dialogue has been established, and is mostly maintained, by psychoanalytically and existentially oriented psychotherapists, who studied with traditional teachers of mindfulness in Asian countries, most of them already mentioned above, such as Jung, Fromm, Kornfield, Epstein, Engler, and Safran (2003). 3) Direct applications of mindfulness strategies and techniques into psychotherapy, be it in the form of custom programs or pre-designed packages of mindfulness-informed psychotherapeutic approaches (which will be described in more detail below). The psychotherapists working in this area for the most part had no clear previous psychotherapeutic identities, like Jon Kabat Zinn, or they were cognitive-behavior therapists, like Mark Williams, Zindel Segal and John Teasdale (working together to promote the concept of Mindfulness-Based Cognitive Therapy). Many of these have not studied from primary sources or teachers within Asian Buddhist traditions, and promote the idea of a theoretically neutral, scientifically based, secularized form of mindfulness practices.

From the therapist's perspective, we can discern three formats of mindfulness-oriented psychotherapists (Germer et al.2013): a) practicing therapists, who practice mindfulness, but do not implement it in their psychotherapeutic work; b) mindfulness-informed psychotherapists, who implement some insights and complement their psychotherapeutic approach with them, and c) mindfulness-based psychotherapists, who directly implement mindfulness techniques into their work. It is important to note at this point that there is a wide spectrum of variety and intensity present when looking at the differences in the theoretical understanding and practical knowledge acquired by individual psychotherapists. Some have a long-standing interest, with thousands of hours of practice and a serious study of mindfulness behind them, while some have just embarked the journey, attended a seminar or two and are already teaching others and treating patients with mindfulness techniques. It thus goes without saying that these are incomparable strands with regard to the psychotherapeutic application of mindfulness, and research that does not clearly consider such differences has no real value.

Where in the landscape of psychotherapy would be an appropriate place for mindfulness? Is cognitive-behavior therapy (CBT) really the most suitable area within which to locate a mindfulness-oriented approach? Another question would be whether we need to attach mindfulness to an existing psychotherapy tradition at all, or can it stand alone as an independent approach? In order to attempt to answer these questions, the relation between mindfulness and individual psychotherapeutic traditions will first be explored. 
What do CBT and mindfulness have in common, and how do they differ? The CBT paradigm, whose pioneer is Aaron Beck (or more precisely the pioneer of its second wave, which is considered the main and most clearly defined CBT theory), focuses on cognitive distortions and behavioral reactions to them as the source of psychological symptoms, and which are thus to be corrected through cognitive, behavioral and relaxation strategies (Beck 2011). Common grounds with mindfulness, which is part of the third wave of CBT (see Hayes 2004), are: working on automatic, habituated psychic patterns; on over-identification with thoughts and cognitive biases or distortions (with significant difference at the cut-off point of what is normal or rational and what is not). They both work primarily on experiences of the present moment, and aim at dehabituation of learned patterns through certain practices (Fennell and Segal 2011). But there are also important differences between the two. The central mechanism of change in mindfulness is the so-called "metacognitive awareness" (Teasdale et al. 2002), described as a change of attitude to one's cognitive patterns, while the primary focus of classical CBT is a change in the cognitive patterns themselves. Furthermore, there are also other important differences, such as the goal of CBT is the correction of cognitive mistakes, while mindfulness seeks the peaceful observation of cognitive processes. The focus of CBT is on an individual's symptoms and abnormal behaviors, while that of mindfulness is on the mental processes underlying all human experiences. The method of CBT is an active struggle with the cognitions in focus, while mindfulness involves an acceptance and withdrawal from all cognitive "actions". The division between the right and correct or normal and the wrong or pathological is also different: for CBT it is in hands of a pre-fixed and therapist-owned rationality, while for mindfulness it is an ultimate goal, equally unreachable by both the patient and therapist. So in many ways mindfulness is not cognitive, but rather anti-cognitive, if we have in mind the classical, i.e. second wave, CBT. Additional and further research thus needs to be conducted in the areas of how, when and on what level can one potentially integrate mindfulness into CBT programs.

What is the relation between mindfulness and psychoanalysis? Psychoanalysis, being a theoretically elaborated approach with several strands, has a long-standing interest in other psychological systems, such as Buddhist psychology. One could think of comparing different psychoanalytic models with mindfulness. For the sake of simplicity and relevance, interpersonal-relational psychoanalysis, which is one of the prevalent theoretical orientations within contemporary psychoanalysis (Fonagy and Target 2003), will be considered here. In contrast to the classical Freudian, drive/structure model, interpersonal-relational psychoanalysis does not understand sexual and aggressive drives as being independent and endogenously emerging. It considers them as responses to the conditions of the outer 
environment, in relation to important others and generated by one's self, which is in tune with the Buddhist distinction between desire as contextually conditioned, and craving as self-generated, repetitive and anxiety-driven behavior. It does not consider the therapist to be an isolated bearer of truth, but a participant observer and co-constructor of the patient's journey out of anxiety and suffering, with this also lying at the heart of mindfulness practice and mindfulness-based psychotherapy. However, there are also important issues and potential disagreements, which should be carefully addressed, and the problem of self is the most prominent of these. Is not the main aim of psychoanalytic psychotherapy strengthening the sense of self, providing firmer borders of the self, with greater self-cohesiveness and sense of identity through good enough relations with others? And is not the aim of mindfulness practice rather the opposite, i.e. to gain the proper insight into the insubstantiality of the self and thus the futility of self-confirmation? Although a detailed exploration of these rich and thought-provoking issues is beyond the scope of this paper, one way of dealing with them could be through adopting the proposition, put forward by Jack Engler among others, that "you have to be somebody before you can be nobody."

Mindfulness has even more affinity and natural synergy with humanistic and existential paradigms. This is the case even if self-actualization, if one takes first the humanistic paradigm into account, meaning the development of human potential, self-transcendence and self-congruence, seems to be rather at odds with the selfless orientation of mindfulness (Beitel et al. 2014), as the humanistic approach does share several common points with the latter. These are acceptance without paralyzing reflection, and autonomy and selflessness in relations to others. Even more in a harmony with mindfulness is the existential paradigm, postulating that the ultimate existential concerns, such as death, (un)freedom, love, meaning(lessness), suffering and isolation are the key sources of human distress, anxiety and all other forms of psychopathology (Yalom 1980). The main axioms of Buddhist psychology are very close and in line with these concerns: suffering and dissatisfaction, and the transience and selflessness of all life's processes. Perhaps mindfulness could thus be seen as the most appropriate method of existential psychotherapy. In other words, one cannot think of many more suitable adjectives to add to mindfulness than existential, and it is certainly more appropriate than cognitive, analytic or systemic.

There is at least one another suitable adjective, though, i.e. phenomenological. The method of mindfulness and the phenomenological method are both good examples of "first-person methodologies", according to Varela and Shear (1999). They both examine descriptions of mental states from first-person perspectives in search of the essential and constitutive elements (Gallagher and Zahavi 2008), 
although they do not share the same goals. The goal of phenomenology is unfolding the maps of human experience, while the goal of mindfulness meditation is liberation from the repetitive patterns of desire $(l o b h a)^{1}$, aversion $(d o s a)$ and ignorance $(m o h a)$.

We can conclude this reflection on the placement of mindfulness within the psychotherapeutic world with the intuition that it belongs to all paradigms, perhaps most naturally to the existential one, but also to none at the same time. Mindfulness has been, and still is, on its own and outside the range of current psychotherapeutic practices, and thus has a vital role in maintaining a continuous dialogue with them.

\section{Research Findings and Research Dilemmas}

The number of scientific papers on mindfulness has risen from zero or one per year in the early 1980s to almost 500 in 2012, with a steady trend seen in this rapid increase. Among these there are many papers focusing on the use of mindfulness to treat diverse medical conditions, both somatic as well as psychic.

Examining all the domains in which mindfulness has been applied is beyond the scope of this article. Nevertheless, a brief overview of some of the most important applications to address disordered and dysfunctional mental states needs to be made, since this is relevant to the further discussion, and so these are outlined as follows. (1) Chronic pain and stress. Mindfulness has been successfully applied to improve the self-regulation of chronic pain (Kabat-Zinn et al. 1985) and thus enhance quality of life, especially in relation to fibromyalgia (Grossman et al., 2007; Schmidt et al., 2011), in women with endometriosis (Kold et al. 2012), and in treating somatization and functional somatic disorders (Fjorback et al. 2012). Such efforts have also been positively evaluated in a meta-analysis (Grossman et al. 2004). (2) Existential pain and anxiety. Mindfulness strategies have been applied to patients with cancer in order to help them find and develop tranquility and a purpose in life, as well as promote personal growth (Labelle et al. 2015), to decrease stress and depression in out-patients with cancer (Speca et al. 2000), and to improve quality of life in women with breast cancer (Hoffman et al. 2012). Lower levels of stress, depression and anxiety have been achieved with the use of mindfulness techniques among patients with cardio-vascular disorders (Abbott et al.2014). (3) Anxiety disorders are one of the most frequently studied

1 The technical Buddhist terms in the text are followed in parentheses by Roman transliterations of the Pāli terms. All Pāli terms presented in the text are transliterated according to the standards and rules of Roman transliteration. 
applications of mindfulness, and this approach has been widely proven to be effective in treating such disorders in general in several meta-analyses (Hofmann et al., 2010; Chen et al. 2012; Vøllestad et al. 2012), as well as in helping with a number of individual anxiety disorders, such as general anxiety disorder (Roemer et al., 2008) or social phobia (Piet et al. 2010). (4) Depressive disorders are another key domain for applications of mindfulness, where the major effect consists of relapse prevention, and on which basis an important approach to mindfulness, called Mindfulness-Based Cognitive Therapy (MBCT) has been established (Segal, Williams and Teasdale 2002). Moreover, mindfulness has consistently been found to underlie the success of this intervention for relapse prevention in depression, as it is the key element of the related treatment program (Teasdale et al., 2000; $\mathrm{Ma}$ and Teasdale 2004), as also seen in meta-analyses of this issue (Hofmann et al. 2010; Fjorback et al. 2012). (5) Addictions have been also studied in relation to mindfulness (Chiesa and Serretti, 2014), especially alcohol addiction (Marlatt and Chawla 2007), craving reduction (Witkiewitz and Bowen 2010) and relapse prevention (Bowen et al. 2014). (6) Mindfulness has been examined in relation to eating disorders (Mateos Rodríguez et al. 2014), for compulsive over-eating (Kristeller and Wolever 2011; Telch et al. 2001), bulimia nervosa (Tapper et al. 2009) and to a lesser extent for anorexia nervosa (Heffner et al. 2002). (7) Psychotic disorders have also been treated with mindfulness techniques, even if some clinicians have expressed reservations about using such methods with this group of patients (Shonin et al. 2014). The results of these studies, however, are encouraging (Khoury et al. 2013), especially in group settings (Chadwick et al. 2005; Gumley et al., 2010; Braehler et al. 2012, Langer et al. 2012). (8) Finally, an increasingly important field of research is sexual disorders and their treatment through mindfulness (Brotto et al. 2008; Silverstein et al. 2011).

Interesting research on mindfulness also comes from neuroscience laboratories, where diverse functional and structural changes in the brain after practicing mindfulness are being studied (Hölzel et al. 2011; Ives-Deliperi et al. 2011).

However, there are many problems in mindfulness research, some of them characteristic of any research into complex mental phenomena and some specific to research into the use of mindfulness in psychotherapy. The most important issue is how to bridge the divide between the first-person perspective of the experience of mindfulness and the third-person perspective that is needed for the operationalization, measurement and evaluation of it. Self-report questionnaires are useful and simple, but what do they actually measure? Prepared and closed questions can assess only a small part of the rich experience of mindfulness. And who has the authority to construct interview instruments or questionnaires, and to evaluate the results? How much practice is necessary before engaging in this? Cognitive 
tests, which measure factors such as focused attention or working memory, can give us information on these processes, but not on mindfulness, which is a qualitatively different experience ( $\mathrm{Jha}$ et al. 2010). Another big dilemma is the influence of practice: if we "measure" mindfulness in novice and more experienced practitioners, do we measure the same thing? If it is "measured" by a newly certified mindfulness-based psychotherapist after a course or two, or by an experienced meditation master who has devoted his or her whole life to this practice, do the two assess the same thing? People practicing mindfulness, as would be the case in any other practice, have a natural tendency and wish to be more mindful. This is reflected in self-reports and eventually in study results. It is also not easy to decipher the correlations that may exist between the practice of mindfulness and any changes that occur as part of psychotherapy (Baer 2011). There are no easy answers to these issues, but one needs to have them in mind when working to achieve higher quality psychotherapy based on mindfulness, as well as the related research.

\section{Concepts and Mechanisms in Applying Mindfulness in Psychotherapy}

We can now turn to the last part of the present paper, i.e. the concepts employed and mechanisms conceptualized to be at play in applying mindfulness in psychotherapy.

Mindfulness in this context was defined by the pioneers in the field as follows. Kabat-Zinn (2005) talks about "open hearted, moment-to-moment, non-judgmental awareness", and Teasdale (2002) about "meta-cognitive awareness" as the key element of mindfulness. In 2004 a group of researchers tried to reach a consensus and a testable operational definition of mindfulness. They proposed a two-component model of mindfulness: (a) self-regulation of attention on immediate experience for increased recognition of mental events in the present moment, and (b) a particular orientation toward one's experiences in the present moment, characterized by curiosity, openness, and acceptance (Bishop et al. 2004).

We can extract three groups of processes from this, which can be considered as the three key mechanisms of change in mindfulness-based psychotherapy. These are: (1) focused attention or concentration, accompanied by tranquility, relaxation, a decrease in anxiety and worries, greater (emotional) stability and joy; (2) open-monitoring (mindfulness per se) with increased (interoceptive) awareness of the body, the emotions and their differentiation (Hill and Updegraff 2012), belief formation, appraisals and other cognitive practices, with concomitant increases in 
the adjustability and flexibility of mental processes (Shapiro et al. 2006); (3) loving kindness and compassion, i.e. a transition from worrisome to loving/accepting attention, providing conditions for positive emotions and stability for psychotherapeutic working-through, and a more compassionate attitude toward life and other beings (Salzberg 2011; Neff et al. 2007).

It is important to have in mind and to differentiate mindfulness from other mental processes. Mindfulness should not be mistaken for: (a) a relaxation technique (many times it is not relaxing); (b) training in concentration only (it is rather training of attention to the flow of consciousness); (c) avoiding problems, difficulties or responsibilities in life (the results should in fact be the opposite, i.e. a confrontation with these); (d) convulsive and controlling (hyper)reflectivity (as opposed to a non-elaborative, and non-reactive awareness); (e) covering or neglecting certain personality traits and/or disorders (mindfulness is instead an endeavor to raise these to a higher level of awareness and thus gain insight into them); and finally, mindfulness should not be mistaken for (f) a search for elevated states of mind, trance, ecstasy or other peak experiences (which can occur as side-effects, but are never a primary goal or focus of mindfulness).

Applications of mindfulness in psychotherapy are often formulated in pre-fixed treatment packages with manuals, recorded materials, and organized courses with certificates, enabling participants to readily apply these in their clinical practice. The most popular and well-known packages of mindfulness-based psychotherapy are Mindfulness-Based Stress Reduction (MBSR) put forward by Kabat-Zinn, and Mindfulness-Based Cognitive Therapy (MBCT) by Segal, Williams and Teasdale (2002). Mindfulness strategies are integral parts of some other important treatment approaches, e.g. Acceptance and Commitment Therapy (ACT), Dialectical Behavioral Therapy (DBT), and Compassion-Focused Therapy (CFT). They have also been integrated into treatment programs for individual mental disorders, e.g. Mindfulness Based Eating Awareness Training (MB-EAT) for binge eating, and Mindfulness Based Relapse Prevention (MBRP) for relapse prevention among addicts. It is important to stress that the formation of such packaged programs is very ambiguous, giving rise to many issues. While it is in some ways a futile endeavor to delve into the details of these programs, suffice to say that the materials they use (e.g. manuals, recordings and so on) should never become a primary resource for learning and practicing mindfulness The multi-faceted history and experiential breadth of mindfulness is too rich to be reduced to such packages. They can be interesting and useful only in offering beginners a structured entry into the field for further exploration using more varied and authentic sources.

It is also important to mention in this context the various problems and side-effects 
arising from the rapid spread, promotion and marketing of certain mindfulness products, such as those offering instant solutions to a range of issues, along with supposedly user-friendly manuals and additional materials in form of recordings and so on. The intentions and interests of the producers and users of these packages might be profiteering or self-promotion, along with the related issues of power, dominance, exploitation and other forms of unethical conduct. We know from the history of religious, spiritual and psychotherapeutic movements that they are far from immune to such corruptions and misuse.

\section{Conclusion}

The discussion presented above has given a brief introduction to the use of mindfulness in psychotherapy, seeing it as a long-lasting, diverse and fecund field. The extremely rapid spread of interest in applications of mindfulness in psychotherapy thus signals a strong need and certain lack in existing psychotherapeutic approaches, which is being addressed with the use of mindfulness. This area therefore provides fertile soil for the transtheoretical search for the key constituents underlying change in psychotherapy. However, as noted in this paper, there are many issues that are now being discussed amongst scientists and scholars from various fields of research related to mindfulness, although some other issues have still not been clearly raised, addressed and explored. The theoretical dialogue between mindfulness in its primary home of Buddhist psychology and the traditional psychotherapeutic paradigms is weak, under-researched and often misleading. Without theoretical reflection, one is like a traveler exploring a vast land without a map. While it is true that maps are not the territory, without them one is less able to explore the land systematically.

In addition to the limited theoretical reflections on the dialogue between mindfulness approaches and existing forms of psychotherapy, there are also many other dilemmas. Applications of mindfulness in clinical settings and in research need their own regional analyses and reflections. Global enthusiasm and the ever growing use of mindfulness in psychotherapy are occurring along with a lack of the seriousness and rigor which are vital for the advancement of the field. This also opens the doors more widely to charlatans and people in search of other goals, like money, power, fame and so on, rather than insight and selfless and compassionate service to other sentient beings. 


\section{References}

Abbott, Rebecca A., et al. 2014. "Effectiveness of Mindfulness-based Stress Reduction and Mindfulness Based Cognitive Therapy in Vascular Disease: A Systematic Review and Meta-analysis of Randomised Controlled Trials." Journal of Psychosomatic Research 76: 341-51.

Baer, Ruth A. 2011. "Measuring Mindfulness.” Contemporary Buddhism: An Interdisciplinary Journal 12: 241-61.

Beck, Judith S. 2011. Cognitive Behavior Therapy. Basics and Beyond. New York: The Guilford Press.

Beitel, Mark, et al. 2014. "Stillness and Motion: An Empirical Investigation of Mindfulness and Self-actualization." Person-Centered E' Experiential Psychotherapies 13: 187-202.

Bishop, Scorr R., et al. 2004. "Mindfulness: A Proposed Operational Definition.” Clinical Psychology: Science and Practice 11: 230-41.

Bowen, Sarah, et al. 2014. "Relative Efficacy of Mindfulness-based Relapse Prevention, Standard Relapse Prevention, and Treatment as Usual for Substance Use Disorders: a Randomized clinical Trial." JAMA Psychiatry 71 (5): 547-56.

Braehler, Christine, et al. 2012. "Exploring Change Processes in Compassion Focused Therapy in Psychosis: Results of a Feasibility Randomized Controlled Trial." British Journal of Clinical Psychology 52: 199-214.

Brotto, Lori, Rosemary Basson, and Mijal Luria. 2008. "A Mindfulness-based Group Psychoeducational Intervention Targeting Sexual Arousal Disorder in Women." Journal of Sexual Medicine 5: 1646-59.

Chadwick, Paul, Katherine N. Taylor, and Nicola Abba. 2005. "Mindfulness Groups for People with Psychosis." Behavioural and Cognitive Psychotherapy 33: 351-9.

Chiesa, Alberto, and Alessandro Serretti. 2014. "Are Mindfulness-Based Interventions Effective for Substance Use Disorders? A Systematic Review of the Evidence." Substance Use E̋ Misuse 49: 492-512.

Chen, Kevin, et al. 2012. "Meditative Therapies for Reducing Anxiety: A Systematic Review and Meta-analysis of Randomized Controlled Trials." Depression and Anxiety 29 (7): 545-62.

Ditrich, Tamara. 2013. "Mindfulness in Modern Buddhism: New Approaches and Meanings." In One Dharma: Many Buddhist Traditions: A Festschrift in Memory of K Sri Dhammananda (1919-2006), edited by B. Liow Woon Khin, 181-90. Petaling Jaya: Buddhist Gem Fellowship.

—. 2016. "Buddhism between Asia and Europe: The Concept of Mindfulness through an Historical Lens." Asian Studies 4 (1): 197-213. 
Fennell, Melanie, and Zindel Segal. 2011. "Mindfulness-based Cognitive Therapy: Culture Clash or Creative Fusion." Contemporary Buddhism 12: 125-42. Fonagy, Peter, and Mary Target. 2003. Psychoanalytic Theories. Perspectives from Developmental Psychopathology. London: Whurr.

Fjorback, Lone O., et al. 2012. "Mindfulness Therapy for Somatization Disorder and Functional Somatic Syndromes - Randomized Trial with One-Year Follow-up." Journal of Psychosomatic Research 74 (1): 31-40.

Gallagher, Shaun, and Dan Zahavi. 2008. The Phenomenological Mind. An Introduction to Philosophy of Mind and Phenomenology. London: Routledge.

Germer, Christopher K., Ronald D. Siegel, and Paul R. Fulton, eds. 2013. Mindfulness and Psychotherapy. New York: The Guilford Press.

Grossman, Paul, et al. 2004. "Mindfulness-based Stress Reduction and Health Benefits. A Meta-analysis." Journal of Psychosomatic Research 57: 35-43.

Grossman, Paul, et al. 2007. "Mindfulness Training as an Intervention for Fibromyalgia: Evidence of Postintervention and 3-Year Follow-up Benefits in Well-Being." Psychotherapy and Psychosomatics 76 (4): 226-33.

Gumley, Andrew, et al. 2010. "A Compassion Focused Model of Recovery after Psychosis.” International Journal of Cognitive Therapy 3 (2): 186-201.

Hayes, Steven C. 2004. "Acceptance and Commitment Therapy, Relational Frame Theory, and the Third Wave of Behavioral and Cognitive Therapies." Behavior Therapy 35: 639-65.

Heffner, Michelle, et al. 2002. "Acceptance and Commitment Therapy in the Treatment of an Adolescent Female with Anorexia Nervosa: A Case Example." Cognitive and Behavioral Practice 9: 232-6.

Hill, Christina L.M., and John A. Updegraff. 2012. "Mindfulness and Its Relationship to Emotion Regulation.” Emotion 12 (1): 81-90.

Hofmann, Stefan G., et al. 2010. "The Effect of Mindfulness-Based Therapy on Anxiety and Depression: A Meta-Analytic Review." Journal of Consulting and Clinical Psychology 78 (2): 169-83.

Hoffman, Caroline J., et al. 2012. "Effectiveness of Mindfulness-Based Stress Reduction in Mood, Breast- and Endocrine-Related Quality of Life, and Well-Being in Stage 0 to III Breast Cancer: A Randomized, Controlled Trial." Journal of Clinical Oncology 30: 1-8.

Hölzel, Britta K., et al. 2011. "How Does Mindfulness Meditation Work? Proposing Mechanisms of Action from a Conceptual and Neural Perspective." Perspectives on Psychological Science 6 (6): 537-59.

Ives-Deliperi, Victoria L., Mark Solms, and Ernesta M. Meintjes. 2011. "The Neural Substrates of Mindfulness: An fMRI Investigation.” Social Neuroscience 6(3): 231-42. 
Jha, Amishi, et al. 2010. "Examining the Protective Effects of Mindfulness Training on Working Memory Capacity and Affective Experience." Emotion 10 (1): 54-64.

Kabat-Zinn, Jon. 2005. Coming to Our Senses: Healing Ourselves and the World Through Mindfulness. New York: Hyperion.

—. 2013. Full Catastrophe Living. How to Cope with Stress, Pain and Illness Using Mindfulness Meditation. London: Piatkus.

Kabat-Zinn, Jon, Leslie Lipworth, and Robert Burney. 1985. "The Clinical Use of Mindfulness Meditation for The Self-Regulation of Chronic Pain.” Journal of Behavioral Medicine 8 (2): 163-90.

Khoury, Bassam, et al. 2013. "Mindfulness-based Therapy: A Comprehensive Meta-analysis." Clinical Psychology Review 33: 763-71.

Kold, Mette, et al.2012. "Mindfulness-based Psychological Intervention for Coping with Pain in Endometriosis." Nordic Psychology 64 (1): 2-16.

Kristeller, Jean L., and Ruth Q. Wolever. 2011. "Mindfulness-based Eating Awareness Training for Treating Binge Eating Disorder: The Conceptual Foundation." Eating Disorders 19 (1): 49-61.

Langer, Alvaro, and Adolfo Cangas. 2012. "Applying Mindfulness Therapy in a Group of Psychotic Individuals: A Controlled Study." Behavioural and Cognitive Psychotherapy 40: 105-9.

Labelle, Laura E., et al. 2015. "Mediators of Mindfulness-Based Stress Reduction (MBSR): Assessing the Timing and Sequence of Change in Cancer Patients." Journal of Clinical Psychology 71 (1): 21-40.

Lenoir, Frédéric. 1999. La rencontre du bouddhisme et de l'Occident. Paris: Fayard.

Ma, Helen, and John Teasdale. 2004. "Mindfulness-based Cognitive Therapy for Depression: Replication and Exploration of Differential Relapse Prevention Effects." Journal of Consulting and Clinical Psychology 72 (1): 31-40.

Marlatt, Alan, and Nitesh Chawla. 2007. "Meditation and Alcohol Use." Southern Medical Journal 100 (4): 451-3.

Mateos Rodríguez, Irene, Felicity A. Cowdrey, and Rebecca J. Park. 2014. "Is There a Place for Mindfulness in the Treatment of Anorexia Nervosa?" $A d-$ vances in Eating Disorders: Theory, Research and Practice 2 (1): 42-52.

Milčinski, Lev. 1990. O mističnem ali meditativnem doživetju. Primorska srečanja 15 (108-109): 383-8.

Neff, Kristin D., Kristin L. Kirkpatrick, and Stephanie S. Rude. 2007. "Self-compassion and Its Link to Adaptive Psychological Functioning." Journal of Resesarch in Personality 41: 139-54.

Pečenko, Primož. 1990. Pot pozornosti. Osnove budistične meditacije. Ljubljana: Domus. 
Piet, Jacob, et al. 2010. "A Randomized Pilot Study of Mindfulness-based Cognitive Therapy and Group Cognitive-behavioral Therapy for Young Adults with Social Phobia." Scandinavian Journal of Psychology 51 (5): 403-10.

Roemer, Lizabeth, Susan Orsillo, and Kristalyn Salters-Pedneault. 2008. "Efficacy of an Acceptance-based Behavior Therapy for Generalized Anxiety Disorder: Evaluation in a Randomized Controlled Trial." Journal of Consulting and Clinical Psychology 76 (6): 1083-9.

Safran, Jeremy D., ed. 2003. Psychoanalysis and Buddhism. An Unfolding Dialogue. Boston: Wisdom Publications.

Salzberg, Sharon. 2011. Real Happiness: The Power of Meditation. New York: Workman.

Schmidt, Stefan, et al. 2011. "Treating Fibromyalgia with Mindfulness-Based Stress Reduction: Results from a 3-armed Randomized Controlled Trial." PAIN 152: 361-9.

Segal, Zindel V., J. Mark G. Williams, and John D. Teasdale. 2002. Mindfulness-based Cognitive Therapy for Depression: A New Approach to Preventing Relapse. New York: Guilford Press.

Shapiro, SL, et al. 2006. "Mechanisms of Mindfulness." Journal of Clinical Psychology 62 (3): 373-86.

Shonin, Edo, et al. 2014. "Do Mindfulness Based Therapies Have a Role in the Treatment of Psychosis?" Australia and New Zealand Journal of Psychiatry 48 (2): 124-7.

Silverstein, Gina, et al. 2011. "Effects of Mindfulness Training on Body Awareness to Sexual Stimuli: Implications for Female Sexual Dysfunction.” Psychosomatic Medicine 73 (9): 817-25.

Speca, Michael, et al. 2000. "A Randomized Wait-List Controlled Trial: The Effects of a Mindfulness Meditation Based Stress Reduction Program on Mood and Symptoms of Stress in Cancer Outpatients." Psychosomatic Medicine 62: 613-22.

Tapper, Katy, et al. 2009. "Exploratory Randomised Controlled Trial of a Mindfulness-Based Weight Loss Intervention for Women." Appetite 52 (2): 396-404. Teasdale, John D., et al. 2000. "Prevention of Relapse/Recurrence in Major Depression by Mindfulness Based Cognitive Therapy." Journal of Consulting and Clinical Psychology 68: 615-23.

Teasdale, John D., et al 2002. "Metacognitive Awareness and Prevention of Relapse in Depression: Empirical Evidence." Journal of Consulting and Clinical Psychology 70: 275-87.

Telch, Christy F., William S. Agras, and Marsha M. Linehan. 2001. "Dialectical Behavior Therapy for Binge Eating Disorder." Journal of Consulting E Clinical Psychology 69 (6): 1061-5. 
Varela, Francisco J., and Jonathan Shear. 1999. "First-person Methodologies: What, Why, How?" Journal of Consciousness Studies 6: 1-14.

Vøllestad, Jon, Morten Nielsen, and Geir Nielsen. 2012. "Mindfulness- and Acceptance-based Interventions for Anxiety Disorders: A Systematic Review and Meta-Analysis." British Journal of Clinical Psychology 51 (3): 239-60.

Witkiewitz, Katie, and Sarah Bowen. 2010. "Depression, Craving, and Substance Use Following a Randomized Trial of Mindfulness-based Relapse Prevention." Journal of Consulting E Clinical Psychology 78 (3): 362-74.

Yalom, I.D. 1980. Existential Psychotherapy. New York: Basic Books. 